\title{
Elemental Selenium Enriched Nanofiber Production
}

\author{
Khandsuren Badgar 1,2,*(D) and József Prokisch 1,2 \\ 1 Institute of Animal Science, Biotechnology and Nature Conservation, Faculty of Agricultural and Food \\ Sciences and Environmental Management, University of Debrecen, 138 Böszörményi Street, \\ 4032 Debrecen, Hungary; jprokisch@agr.unideb.hu \\ 2 Doctoral School of Animal Science, University of Debrecen, 138 Böszörményi Street, 4032 Debrecen, Hungary \\ * Correspondence: b_khandsuren@muls.edu.mn; Tel.: +36-203413997
}

Citation: Badgar, K.; Prokisch, J.

Elemental Selenium Enriched Nanofiber Production. Molecules 2021, 26, 6457. https://doi.org/10.3390/ molecules 26216457

Academic Editors: Jian Fang and Hao Shao

Received: 9 September 2021

Accepted: 24 October 2021

Published: 26 October 2021

Publisher's Note: MDPI stays neutral with regard to jurisdictional claims in published maps and institutional affiliations.

Copyright: (c) 2021 by the authors. Licensee MDPI, Basel, Switzerland. This article is an open access article distributed under the terms and conditions of the Creative Commons Attribution (CC BY) license (https:/ / creativecommons.org/licenses/by/ $4.0 /)$.

\begin{abstract}
This study aimed to produce electrospun nanofibers from a polyvinyl butyral polymer (PVB) solution enriched with red and grey selenium nanoparticles. Scanning electron microscopic analysis was used to observe the samples, evaluate the fiber diameters, and reveal eventual artifacts in the nanofibrous structure. Average fiber diameter is determined by manually measuring the diameters of randomly selected fibers on scanning electron microscopic (SEM) images. The obtained nanofibers are amorphous with a diameter of approximately $500 \mathrm{~nm}$, a specific surface area of approx. $8 \mathrm{~m}^{2} \mathrm{~g}^{-1}$, and $5093 \mathrm{~km} \mathrm{~cm}^{-3}$ length. If the red and grey selenium nanoparticles were produced in powder form and suspended to the ethanolic solution of PVB then they were located inside and outside the fiber. When selenium nanoparticles were synthesized in the PVB solution, then they were located only inside the fiber. These nanofiber sheets enriched with selenium nanoparticles could be a good candidate for high-efficiency filter materials and medical applications.
\end{abstract}

Keywords: selenium nanoparticles; nanopowder; nanofibers; electrospinning

\section{Introduction}

Electrospun nanofibers have attracted great attention owing to their unique features such as high specific surface areas, high porosity, and interconnected pore structure. Due to these properties, they have been used infiltration [1,2], nanocomposites [3,4], biological functional tissue scaffolds [5-7], protective textiles [8,9], catalysis [10,11], drug delivery systems [6,12], etc. The electrospinning process is a straightforward experimental setup that spins diameters ranging from $10 \mathrm{~nm}$ to several hundred nanometers. The nanofibers have been successfully produced by the electrospinning technique from many types of synthetic and natural polymers. Electrospinning allows the fabrication of ultrathin fiber mats with an extraordinary control of their structure and properties. It is an ideal alternative for applications such as wound healing or even functional membranes. Control of reactive oxygen species (ROS) at the injury site plays a major role in the wound healing process. This multi-step process includes hemostasis, inflammation, proliferation, and maturation phases $[13,14]$. A high level of ROS could damage normal cells during the inflammatory phase, which is released from neutrophils cells to fight microbes $[15,16]$. In this case, applying antioxidant agents could accelerate wound healing by reducing the adverse effects of ROS [17]. Based on these, functional nanofibers have been engaging in the production of electrospun nanofibrous membranes. Recently, the production of functional electrospun nanofiber with additives, especially nanoparticles with therapeutic and preventive effects, has been a new challenge. There are few studies reported that silver nanoparticles (AgNPs) [18,19], copper nanoparticles (CuNPs) [20], gold nanoparticles (AuNPs) [21], cerium oxide nanoparticles (CeNPs) [22], selenium nanoparticles (SeNPs) [3,23] have been used for the fabrication of nanomaterials based on their antioxidant and antibacterial properties. Definitely, selenium nanoparticle is a good candidate for the development of functional properties of nanomaterials according to its high antioxidant [24], anticancer [25-27], detoxification [28,29], antibacterial [30-33], antifungal [34,35], and antiviral effects [36]. However, 
a limited number of studies were found involving electrospun nanofibers functionalized by selenium nanoparticles $[3,23,37,38]$. Chung and co-workers reported that silk scaffolds functionalized by selenium nanoparticles were significantly increased bacterial inhibition. In other words, it was dramatically improved the short-term human dermal fibroblast metabolic activity while reducing the ATP content of Staphylococcus aureus [3]. A recent study reported the effect of nanofiber functionalized by selenium nanoparticles in the application of wound healing. Nanofibers with selenium nanoparticles and vitamin $\mathrm{E}$ produced from polycaprolactone/gelatin have supported the proliferation and attachment of fibroblast 3T3 cells by reducing edema, inflammation, and oxidative stress at the site of injury [23]. This study tested red and grey selenium nanoparticles with polyvinyl butyral (PVB) polymer to produce nanofibers by the electrospinning method. PVB is one of the polymers that have been extensively used in many applications since PVB is a low-cost alternative, showing flexibility, optical clarity, and good adhesion to many surfaces. Furthermore, the PVB is insoluble water; therefore, it is possible to filtrate aqueous solutions. However, few studies have been performed to date on the usage of PVB in the fabric of electrospun nanofibers [39-43]. In addition, few cell cultures studies have been performed on this material and were based on films made by solvent casting and nanoparticles as prospective candidates in alveolar bone substitutes, drug delivery systems, or contrasting agents in cancer therapy $[44,45]$.

\section{Results and Discussion}

In electrospinning, the process parameters (type of polymer and solvent, viscosity, concentration, net charge density, and surface tension of the polymer fluid) and the system parameters (voltage, flow rate of polymer solution, distance between capillary end and collector, ambient parameters, and motion of collector) have a crucial role in fiber morphology [46]. In our study, ten $\mathrm{mL} \mathrm{h}^{-1}$ of flow rate, $25 \mathrm{~cm}$ of distance between stainless-steel collector and needle tip, $40 \mathrm{kV}$ of voltage, $10 \%$ of PVB polymer dissolved in ethanol were compatible in the electrospinning process at the humidity $34 \%$ and temperature $24{ }^{\circ} \mathrm{C}$. Also, the viscosity and density of PVB were found $474 \mathrm{~mm}^{2} \mathrm{~s}^{-1}, 0.81 \mathrm{~g} \mathrm{~mL}^{-1}$, respectively. It is reported that all solutions based on isopropanol, butanol, and ethanol were suitable solvents for PVB in the production of nanofiber [39]. Ten percent of PVB polymer was suitable for resuspension selenium nanopowder, as presented in Figure 5. First, the morphology of nanofiber was checked under a simple light microscope with $400 \times$ magnification. A few layers of nanofiber were covered on the coverslip. Nanofibers have cylinder shapes with multi structures such as linear, spiral, zigzag lines, etc. as shown in Figure 1. It was a simple way of checking the morphology and structure of nanofibers.
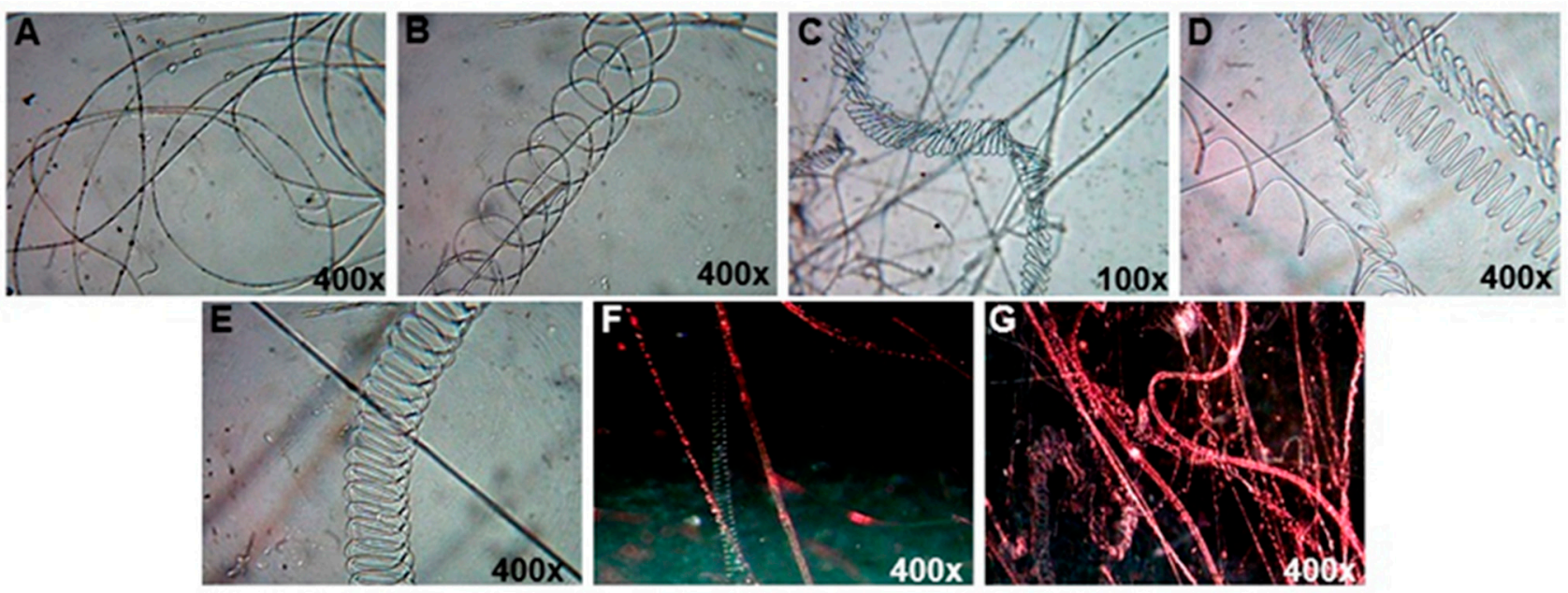

Figure 1. The multiple structures of nanofibers enriched by selenium nanoparticles; (A,B): red selenium nanopowder, $(\mathbf{C})$ : grey selenium nanopowder, (D-G): aqueous-ethanol SeNPs. The light microscopy pictures were made with white light and red laser illumination. 
Up to $10 \%$ of red and grey selenium nanopowder contained PVB polymer solution was suitable for nanofiber formation. The color of the fiber sheet has also increased with the increment of the concentration of selenium nanopowder. 10\% of red and grey selenium nanopowder resulted in brighter pink and black nanofiber (Figure 2). There was no difference in the nanofibers' diameter size or morphology and electrospinning process between amorphous and crystalline forms of selenium. The surface of all-fiber sheets was contained various concentrations of selenium nanopowder that were smooth and flexible. However, their high concentrations were affected by the viscosity, density, and conductivity of polymer solution. Thus, the production rate slowed down.
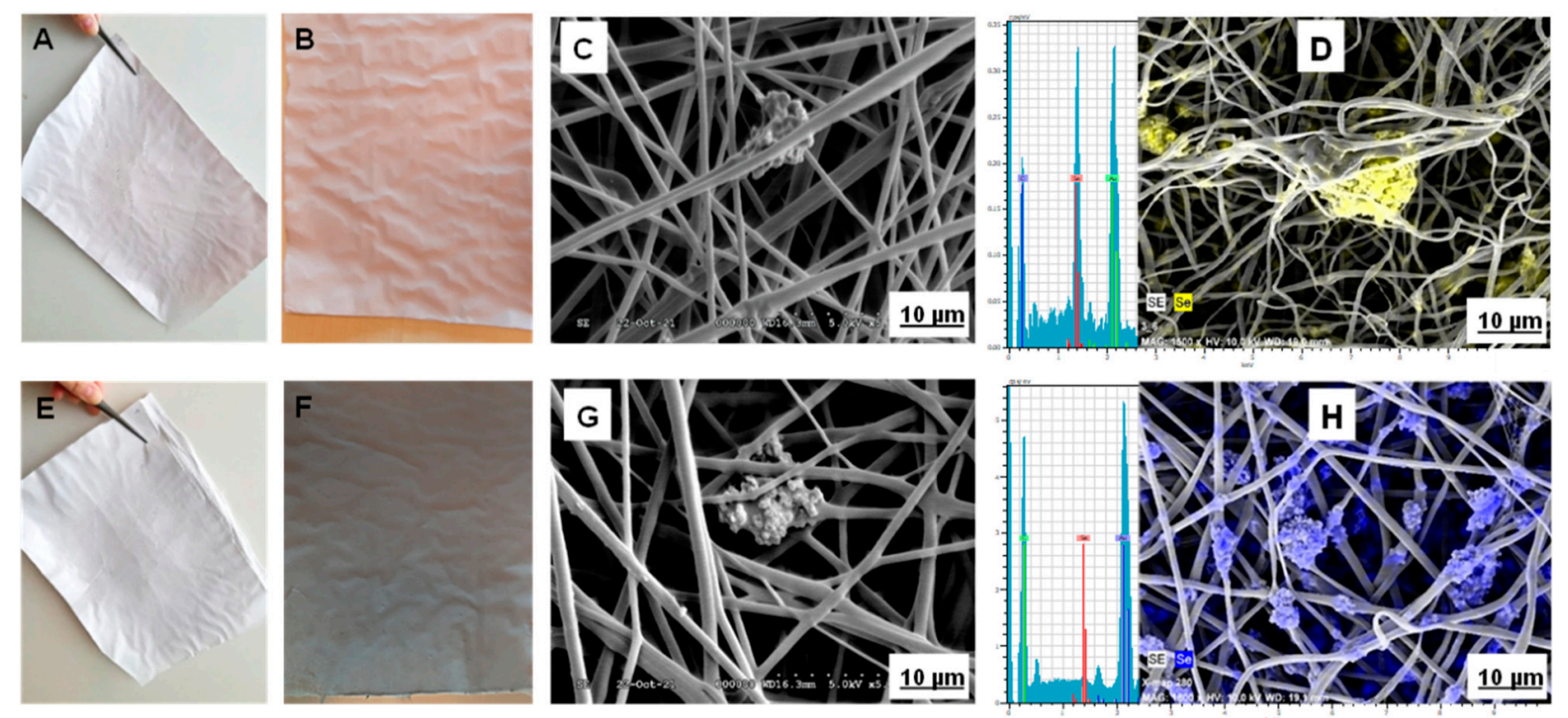

Figure 2. Nanofiber sheets enriched by selenium nanopowder and their SEM images with EDS; (A,C): 1\% red selenium, (B,D): 10\% red selenium, (E,G): 1\% grey selenium, (F,H): 10\% grey selenium.

The morphology and diameter of red and grey selenium nanopowder enriched nanofiber was determined by scanning electron microscope with X-ray and EDS (Figure 2). The selenium nanoparticle's beads were loaded inside and outside the nanofibers confirmed by X-Ray and EDS analysis. Generally, it is an essential technique for the observation of nanofibrous structures. As a result, increasing the concentration of nanopowder from 1 to $10 \%(w / v)$ resulted in the increased formation of beads. Similar to our finding, Kamaruzaman et al. reported that the formation of beads increases by the high concentration of selenium nanoparticles in the polymer [38]. Particles are structured at different scales due to solid interaction, resulting in chain-like structures. The aggregation of nanoparticles develops the bead formation during the electrospinning process, which causes a higher relative surface area and a higher relative number of surface atoms. Thus, the advantages of bead formation are to be load more selenium in sheet and increase its releasing and positive effects on the surface. Due to these advantages, red and grey selenium nanopowder embedded nanofibers are more suitable for filtration design in water and air, and the wound healing process. However, the chain-like structure of beads may affect fiber's strength. The obtained nanofibers are prevalently amorphous with diameters ranging from 100 to $1000 \mathrm{~nm}$ and a specific surface area of approximately $4-40 \mathrm{~m}^{2} \mathrm{~g}^{-1}$. The average diameter of fibers was about $500 \mathrm{~nm}$, and specific surfaces area $8 \mathrm{~m}^{2} \mathrm{~g}^{-1}$ for all selenium nanopowder concentrations. The fiber's length was calculated from their diameter based on the equation for the volume and surface of cylinders. In this case, $1 \mathrm{~mL}$ of $10 \%$ polymer solution was originated from $500 \mathrm{~nm}$ wide nanofiber, their length was $5093 \mathrm{~km} \mathrm{~cm}{ }^{-3}$. 
In the next section, selenium nanoparticles were synthesized in the PVB polymer after then nanofibers were produced. In a typical procedure, $500 \mathrm{mg} \mathrm{dm}^{-3}$ of sodium selenite and $10 \mathrm{~g} \mathrm{dm}^{-3}$ of ascorbic acid were dissolved in $80 \%$ of ethanol by ultrasonication for $30 \mathrm{~min}$. Then, $10 \%$ of PVB was added to each, and the mixture was ultrasonicated for $30 \mathrm{~min}$. The sodium selenite and ascorbic acid-enriched PVB were kept at room temperature for a day, separately too. On the next day, these solutions were mixed in the same ratio at ultrasonic for $30 \mathrm{~min}$ (SeNPs-PVB). At the end of the reaction time, the color of the solution was turned red. In the final step, SeNPs-PVB solution was diluted with pure PVB solution in the same ratio (shown in Figure 5C). Because $80 \%$ of ethanol was not good for electrospinning, it was changed conductivity. The reduction process was similar to the previous experiment regarding reaction time and color change [47]. Our earlier study found that selenium nanoparticles aggregate to a large extent in a liquid, and the size of the aggregates grew up to $100 \mu \mathrm{m}$ by reaction time [48]. Smaller particles readily interact with each other to form larger particle sizes [49]. The agglomeration occurs when surface atoms of nanoparticles tend to form bonds due to the smaller size of the nanoparticles. Nevertheless, PVB polymer solution does not include any large aggregate of selenium nanoparticles, and it was a good stabilizer. Also, PVB is completely non-toxic. Due to its composition of only carbon, hydrogen, and oxygen, it combusts with almost no residue, which resulted in its widespread use in food packaging. As a result, we have a good fiber sheet with light pink, smooth and soft, which is contained $1250 \mathrm{mg} \mathrm{dm}^{-3}$ of selenium (Figure 3). A scanning electron microscope also characterized the morphology, diameter, and location of selenium nanoparticles. The selenium nanoparticles, which are well dispersed in the PVB solution, played an important factor in the fabrication of high-quality nanofibers. There are no particles on the outside of the fiber that was indicated by electron microscopic images (Figure 3). The absence of selenium nanoparticles on the outside of the fiber was visible under an electron microscope. All the selenium nanoparticles with a diameter of $50 \mathrm{~nm}$ or smaller are located on the inside of the fiber. The mean diameter of fibers was $500 \mathrm{~nm}$. Their specific surface area and length are also similar to the previous results. It was our hypothesis for this section of the experiment. This result was confirmed that any selenium nanoparticles do not affect the morphology of the nanofibers. The produced fiber sheets are new material. Also, it is a new challenge for the production of functional nanofiber. The functional nanofiber, in particular, has attained a greater interest in recent years. The applications of functional nanofibers are increasing in various technical fields including filtration [50,51], tissue engineering [3,7], drug delivery systems [12], wound dressings [21,23], and antibacterial [18,22]. Thus, selenium nanoparticles enriched nanofibers could be good material for medical technology in improving wound healing and reducing infection without antibiotics. Especially, it has the potential to be applied in skin tissue and filtration. From the previous study, selenium nanoparticles have shown antioxidant [24], anticancer [25-27], antibacterial [30-33], and antifungal properties [34,35]. For instance, the addition of selenium nanoparticles in nanomaterials improved fibroblast's metabolic activity while reducing the ATP content of S. aureus [3] and completed re-epithelization [23] for skin application. 

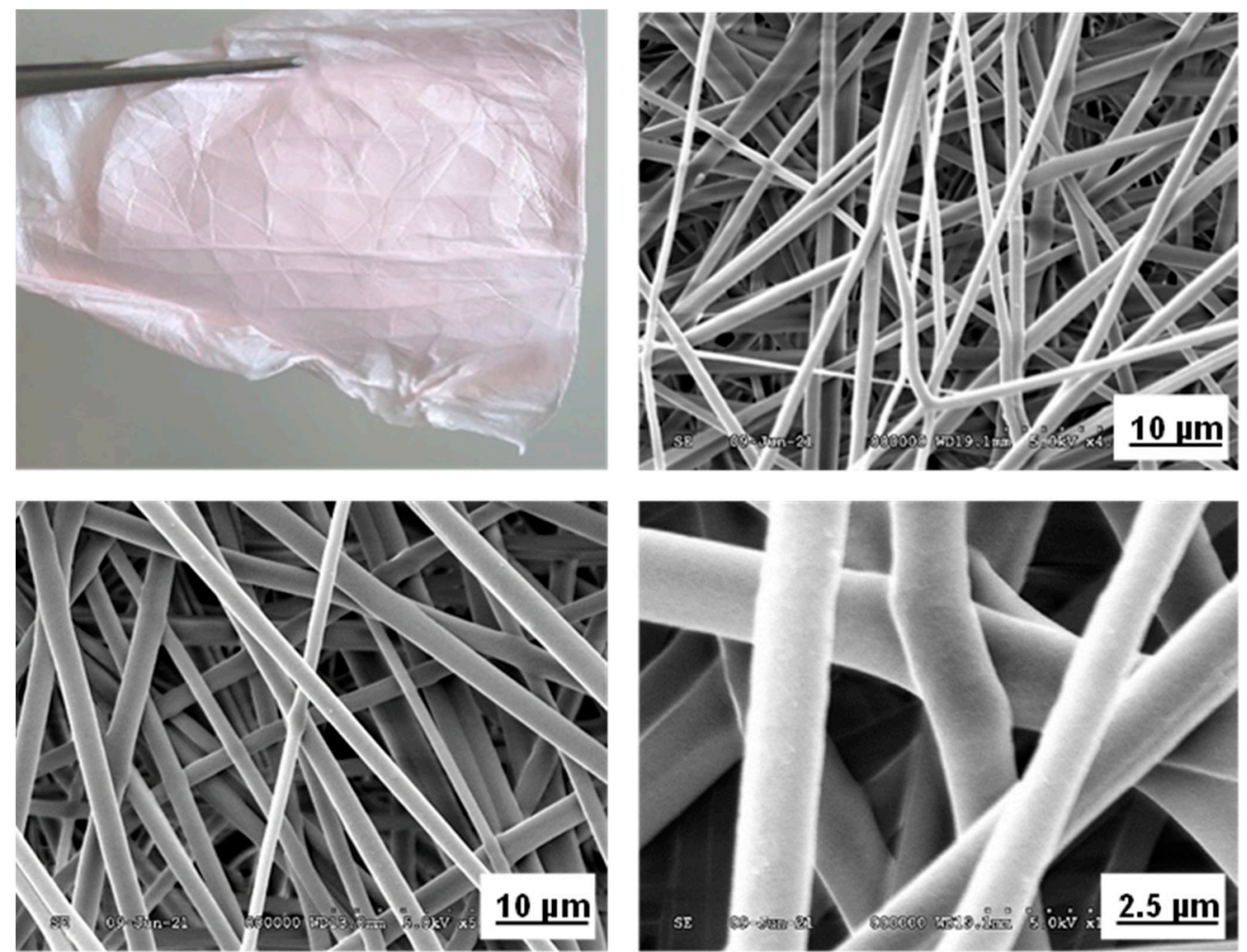

Figure 3. Nanofiber sheet enriched by aqueous-ethanol SeNPs and its SEM images.

\section{Materials and Methods}

Sodium selenite $\left(\mathrm{Na}_{2} \mathrm{SeO}_{3}\right)$ and ascorbic acid $\left(\mathrm{C}_{6} \mathrm{H}_{8} \mathrm{O}_{6}\right)$ were purchased from VWR International Ltd. (Lutterworth, Leics. UK). Ethanol (ethyl alcohol) was purchased from Nógrádi Vegyipari Zrt (Tolmács, Hungary). Polyvinyl butyral (PVB, Mowital LPB 16H, molar mass $16 \mathrm{kDa}$ ) was purchased from Kuraray Europe GmbH D-65926 (Frankfurt am Main, Germany).

\subsection{Preparation of Selenium Nanoparticles}

A modified green chemical reduction method was used for the synthesis of selenium nanoparticles [47].

Selenium nanogranules were prepared according to our previous method [48]. Briefly, $10,000 \mathrm{mg} \mathrm{dm}^{-3}$ of selenium in the form of sodium selenite solution and $100 \mathrm{~g} \mathrm{dm}^{-3}$ of ascorbic acid was mixed at the same ratio, and the mixture was kept at room temperature for $2 \mathrm{~h}$. At the end of the reaction, nanogranules were filtered by a filter paper and washed with alcohol and distilled water 3 times. The red nanogranules were dried at $4{ }^{\circ} \mathrm{C}$ for several days (Figure 4). Grey hexagonal selenium nano granules were prepared from the dried red selenium suspension keeping it at the temperature of $85^{\circ} \mathrm{C}$ for $10 \mathrm{~min}$. Finally, red and grey selenium nano-granules were powdered by a nano grinder. These allotropes of selenium were identified by $\mathrm{X}$-ray diffraction analysis (Figure 4). 


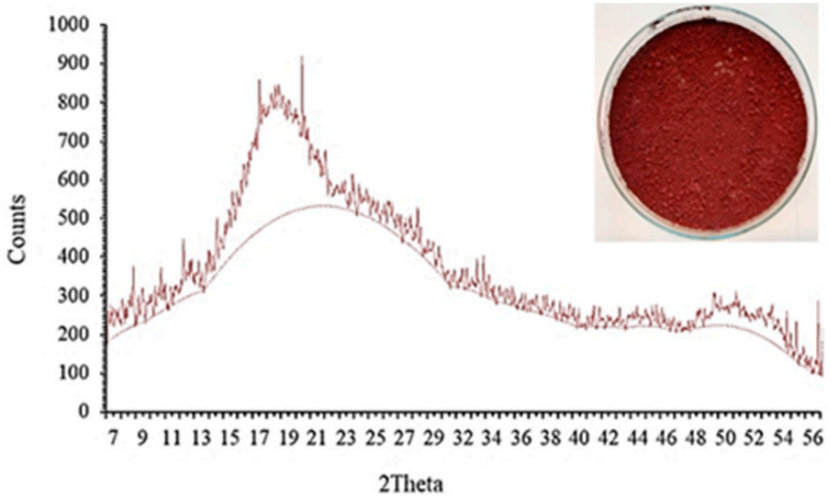

(A)

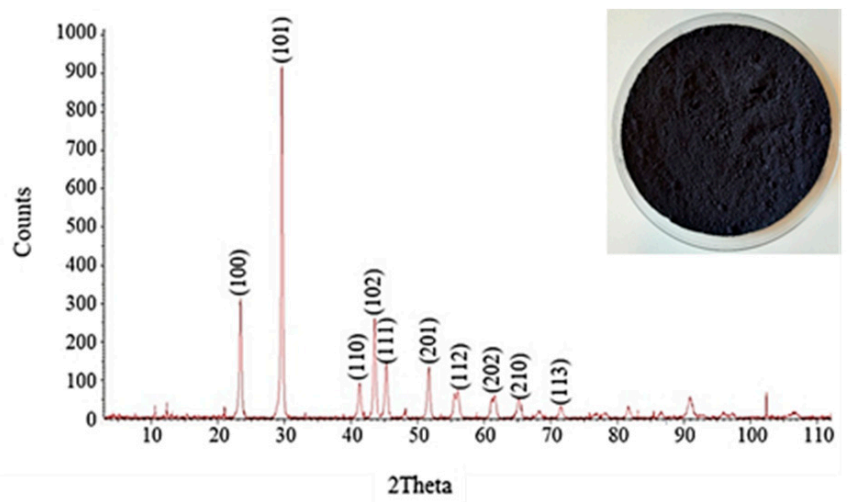

(B)

Figure 4. XRD pattern with red (A) and grey (B) selenium nanopowder.

\subsection{Preparation of SeNPS-PVB Solution}

Ten percent of polyvinyl butyral (PVB) solution was dissolved in absolute ethanol under constant stirring at room temperature until the solution was transparent. The solutions were left standing without stirring for at least a day. Three types of seleniumenriched polymer solution were prepared for the experiment. Two solutions contained the previously prepared red and grey selenium nanopowder. Various red and grey nanopowder $(1,3,5,10 \% w / v)$ were infused in the PVB solution and sonicated for 30 min (Figure 5A,B). The third polymer solution was prepared a different way. The sodium selenite and the ascorbic acid were dissolved in $80 \%$ of ethanol- $20 \%$ of water solution separately, then $10 \%$ of PVB polymer was dissolved After dissolution, the two solutions were mixed in a 1:1 ratio at room temperature to produce selenium nanoparticles (Figure 5C).

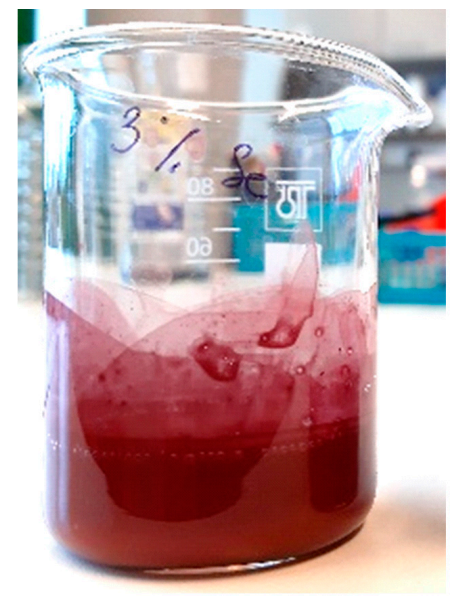

(A)

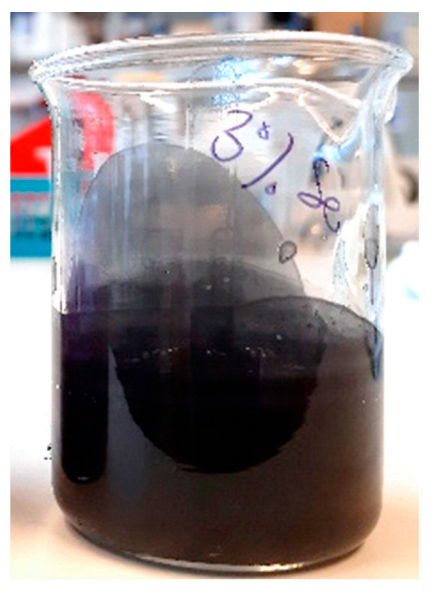

(B)

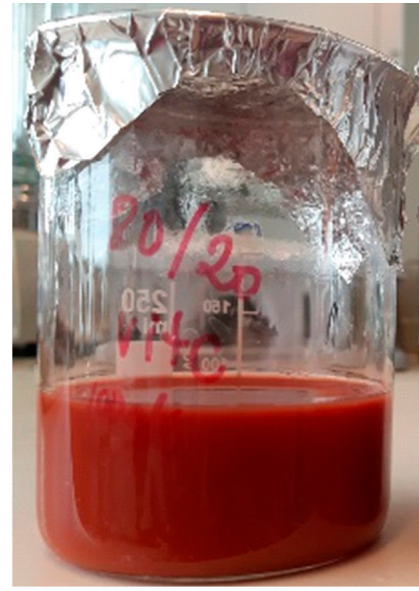

(C)

Figure 5. PVB polymer solution enriched with red (A), grey selenium nanopowder (B), and aqueousethanol SeNPs (C).

\subsection{Electrospinning}

PVB polymer solution was enriched with 2 types of selenium nanoparticles at various concentrations and was used to produce nanofibers by horizontal electrospinning setup. The polymer solution was loaded in a $50 \mathrm{~mL}$ syringe and injected through a stainless-steel blunt-ended needle at a flow rate of $10 \mathrm{~mL} \mathrm{~h}^{-1}$. The nanofibers were collected on the stainless-steel collector placed at a distance of $25 \mathrm{~cm}$ from the tip of the needle under a voltage of $40 \mathrm{kV}$ (voltage power supply NT-45/P, RWT Vasúttechnikai Kft) at the humidity 
(RH) $34 \%$ and temperature at $24{ }^{\circ} \mathrm{C}$. The length of fiber is calculated according to the following Equation (1):

$$
l=\frac{4 V}{d^{2} \pi}
$$

where "l" is the length of fiber in meter, " $V$ " is the volume in $\mathrm{m}^{3}$, " $d$ " is the diameter in meter.

\subsection{Specimen Characterization}

Morphological and microstructural features of the fibers were investigated by fieldemission scanning electron microscopy (SEM), by using a Hitachi S-4300 with Energydispersive X-ray (EDS) analysis, and simple light microscope (Visiscope ${ }^{\circledR} 260$, VWR). The samples were collected on glass slides and textile covered stainless-steel collector for characterization.

\section{Conclusions}

Our work studied the presence of selenium nanoparticles in powder and aqueous for the enrichment of electrospun nanofiber. The average size of originated fibers is approx. $500 \mathrm{~nm}$, specific surface area $8 \mathrm{~m}^{2} \mathrm{~g}^{-1}$, and their length was $5093 \mathrm{~km} \mathrm{~cm}^{-3}$ for all used selenium nanoparticles were obtained. In our study, we obtained that the allotropes of selenium have no effects on the morphology and diameter of the nanofibers. The different selenium allotropes would have a difference in the solubility and the adsorption potential of mercury vapor. The presence of selenium nanopowder distributed beads on the outside and inside of the fiber. Increasing the concentration of selenium nanopowder has increased the formation of beads. When selenium nanoparticles are synthesized in the PVB solution, then the selenium nanoparticles are inside the fiber, the size is much smaller than $50 \mathrm{~nm}$. Thus, the originated fibers were formed with uniform diameter and smooth surface. Further works are required to study the efficiency of filters produced from the selenium-enriched PVB nanofibers.

Author Contributions: Conceptualization K.B. and J.P.; methodology K.B. and J.P.; carried out the experiments K.B. and J.P.; data analyze K.B. and J.P.; writing—original draft preparation K.B. and J.P. All authors have read and agreed to the published version of the manuscript.

Funding: This research was funded by the Stipendium Hungaricum Scholarship Program (SH ID: 140993).

Institutional Review Board Statement: Not applicable.

Informed Consent Statement: Not applicable.

Data Availability Statement: The data presented in this study are available on request from the corresponding author.

Acknowledgments: The authors wish to thank Lajos Daróczy (Department of Solid-State Physics, University of Debrecen) for help with the scanning electron microscopic pictures.

Conflicts of Interest: We declare that there is no conflict of interest.

Sample Availability: Samples of the compounds are available from the authors.

\section{References}

1. Solomin, E.V.; Sirotkin, E.A.; Sirotkin, A.A. Universal Electrospinning Scalable Plant for Filtering Nanofiber Production. Procedia Eng. 2017, 206, 1371-1375. [CrossRef]

2. Sundarrajan, S.; Tan, K.L.; Lim, S.H.; Ramakrishna, S. Electrospun nanofibers for air filtration applications. Procedia Eng. 2014, 75, 159-163. [CrossRef]

3. Chung, S.; Ercan, B.; Roy, A.K.; Webster, T.J. Addition of selenium nanoparticles to electrospun silk scaffold improves the mammalian cell activity while reducing bacterial growth. Front. Physiol. 2016, 7, 297. [CrossRef] [PubMed]

4. Kang, M.; Jung, R.; Kim, H.-S.; Youk, J.H.; Jin, H.-J. Silver nanoparticles incorporated electrospun silk fibers. J. Nanosci. Nanotechnol. 2007, 7, 3888-3891. [CrossRef] 
5. Huang, L.; Nagapudi, K.; Apkarian, R.P.; Chaikof, E.L. Engineered collagen-PEO nanofibers and fabrics. J. Biomater. Sci. Polym. Ed. 2001, 12, 979-993. [CrossRef]

6. Matthews, J.A.; Wnek, G.E.; Simpson, D.G.; Bowlin, G.L. Electrospinning of collagen nanofibers. Biomacromolecules 2002, 3, 232-238. [CrossRef]

7. Shin, M.; Yoshimoto, H.; Vacanti, J.P. In vivo bone tissue engineering using mesenchymal stem cells on a novel electrospun nanofibrous scaffold. Tissue Eng. 2004, 10, 33-41. [CrossRef]

8. Montazer, M.; Shamei, A.; Alimohammadi, F. Synthesis of nanosilver on polyamide fabric using silver/ammonia complex. Mater. Sci. Eng. C 2014, 38, 170-176. [CrossRef] [PubMed]

9. Yuan, G.; Cranston, R. Recent advances in antimicrobial treatments of textiles. Text. Res. J. 2008, 78, 60-72. [CrossRef]

10. Jia, H.; Zhu, G.; Vugrinovich, B.; Kataphinan, W.; Reneker, D.H.; Wang, P. Enzyme-carrying polymeric nanofibers prepared via electrospinning for use as unique biocatalysts. Biotechnol. Prog. 2002, 18, 1027-1032. [CrossRef] [PubMed]

11. Rodriguez, N.M.; Kim, M.-S.; Baker, R.T.K. Carbon nanofibers: A unique catalyst support medium. J. Phys. Chem. 1994, 98, 13108-13111. [CrossRef]

12. Kenawy, E.-R.; Gary, L.B.; Kevin, M.; John, L.; David, G.S.; Elliot, H.S.; Gary, E.W. Release of tetracycline hydrochloride from electrospun poly(ethylene-co-vinylacetate), poly(lactic acid), and a blend. J. Control. Release 2002, 81, 57-64. [CrossRef]

13. Rieger, K.A.; Birch, N.P.; Schiffman, J.D. Designing electrospun nanofiber mats to promote wound healing-A review. J. Mater. Chem. B 2013, 1, 4531-4541. [CrossRef] [PubMed]

14. Selvaraj, S.; Fathima, N.N. Fenugreek incorporated silk fibroin nanofibers-A potential antioxidant scaffold for enhanced wound healing. ACS Appl. Mater. Interfaces 2017, 9, 5916-5926. [CrossRef]

15. Mittal, M.; Siddiqui, M.R.; Tran, K.; Reddy, S.P.; Malik, A.B. Reactive oxygen species in inflammation and tissue injury. Antioxid. Redox Signal. 2014, 20, 1126-1167. [CrossRef] [PubMed]

16. Gallego-Villar, L.; Pérez, B.; Ugarte, M.; Desviat, L.R.; Richard, E. Antioxidants successfully reduce ROS production in propionic acidemia fibroblasts. Biochem. Biophys. Res. Commun. 2014, 452, 457-461. [CrossRef]

17. Gomathi, K.; Gopinath, D.; Rafiuddin Ahmed, M.; Jayakumar, R. Quercetin incorporated collagen matrices for dermal wound healing processes in rat. Biomaterials 2003, 24, 2767-2772. [CrossRef]

18. Aadil, K.R.; Mussatto, S.I.; Jha, H. Synthesis and characterization of silver nanoparticles loaded poly(vinyl alcohol)-lignin electrospun nanofibers and their antimicrobial activity. Int. J. Biol. Macromol. 2018, 120, 763-767. [CrossRef]

19. Pan, S.-F.; Ke, X.-X.; Wang, T.-Y.; Liu, Q.; Zhong, L.-B.; Zheng, Y.-M. Synthesis of silver nanoparticles embedded electrospun PAN nanofiber thin-film composite forward osmosis membrane to enhance performance and antimicrobial activity. Ind. Eng. Chem. Res. 2019, 58, 984-993. [CrossRef]

20. Vijayakumar, V.; Samal, S.K.; Mohanty, S.; Nayak, S.K. Recent advancements in biopolymer and metal nanoparticle-based materials in diabetic wound healing management. Int. J. Biol. Macromol. 2019, 122, 137-148. [CrossRef]

21. Leu, J.G.; Chen, S.A.; Chen, H.M.; Wu, W.M.; Hung, C.F.; Yao, Y.D.; Tu, C.S.; Liang, Y.J. The effects of gold nanoparticles in wound healing with antioxidant epigallocatechin gallate and $\alpha$-lipoic acid. Nanomed. Nanotechnol. Biol. Med. 2012, 8, 767-775. [CrossRef]

22. Rather, H.A.; Thakore, R.; Singh, R.; Jhala, D.; Singh, S.; Vasita, R. Antioxidative study of Cerium oxide nanoparticle functionalised PCL-Gelatin electrospun fibers for wound healing application. Bioact. Mater. 2018, 3, 201-211. [CrossRef]

23. Doostmohammadi, M.; Forootanfar, H.; Shakibaie, M.; Torkzadeh-Mahani, M.; Rahimi, H.R.; Jafari, E.; Ameri, A.; Amirheidari, B. Bioactive anti-oxidative polycaprolactone/gelatin electrospun nanofibers containing selenium nanoparticles/vitamin E for wound dressing applications. J. Biomater. Appl. 2021, 36, 193-209. [CrossRef]

24. Wang, H.; Zhang, J.; Yu, H. Elemental selenium at nano size possesses lower toxicity without compromising the fundamental effect on selenoenzymes: Comparison with selenomethionine in mice. Free Radic. Biol. Med. 2007, 42, 1524-1533. [CrossRef]

25. Bao, P.; Chen, Z.; Tai, R.-Z.; Shen, H.-M.; Martin, F.L.; Zhu, Y.-G. Selenite-induced toxicity in cancer cells is mediated by metabolic generation of endogenous selenium nanoparticles. J. Proteome Res. 2015, 14, 1127-1136. [CrossRef]

26. Luo, H.; Wang, F.; Bai, Y.; Chen, T.; Zheng, W. Selenium nanoparticles inhibit the growth of HeLa and MDA-MB-231 cells through induction of S phase arrest. Colloids Surf. B Biointerfaces 2012, 94, 304-308. [CrossRef] [PubMed]

27. Pi, J.; Yang, F.; Jin, H.; Huang, X.; Liu, R.; Yang, P.; Cai, J. Selenium nanoparticles induced membrane bio-mechanical property changes in MCF-7 cells by disturbing membrane molecules and F-actin. Bioorg. Med. Chem. Lett. 2013, 23, 6296-6303. [CrossRef] [PubMed]

28. Prasad, K.S.; Selvaraj, K. Biogenic synthesis of selenium nanoparticles and their effect on As(III)-induced toxicity on human lymphocytes. Biol. Trace Elem. Res. 2014, 157, 275-283. [CrossRef] [PubMed]

29. Trabelsi, H.; Azzouz, I.; Ferchichi, S.; Tebourbi, O.; Sakly, M.; Abdelmelek, H. Nanotoxicological evaluation of oxidative responses in rat nephrocytes induced by cadmium. Int. J. Nanomed. 2013, 8, 3447-3453. [CrossRef]

30. Fardsadegh, B.; Vaghari, H.; Mohammad-Jafari, R.; Najian, Y.; Jafarizadeh-Malmiri, H. Biosynthesis, characterization and antimicrobial activities assessment of fabricated selenium nanoparticles using Pelargonium zonale leaf extract. Green Process. Synth. 2019, 8, 191-198. [CrossRef]

31. Jackman, J.A.; Lee, J.; Cho, N.-J. Nanomedicine for infectious disease applications: Innovation towards broad-spectrum treatment of viral infections. Small 2016, 12, 1133-1139. [CrossRef] [PubMed]

32. Menon, S.; Agarwal, H.; Rajeshkumar, S.; Jacquline Rosy, P.; Shanmugam, V.K. Investigating the antimicrobial activities of the biosynthesized selenium nanoparticles and its statistical analysis. Bionanoscience 2020, 10, 122-135. [CrossRef] 
33. Shoeibi, S.; Mashreghi, M. Biosynthesis of selenium nanoparticles using Enterococcus faecalis and evaluation of their antibacterial activities. J. Trace Elem. Med. Biol. 2017, 39, 135-139. [CrossRef]

34. Gunti, L.; Dass, R.S.; Kalagatur, N.K. Phytofabrication of selenium nanoparticles from emblica officinalis fruit extract and exploring its biopotential applications: Antioxidant, antimicrobial, and biocompatibility. Front. Microbiol. 2019, 10, 931. [CrossRef]

35. Fardsadegh, B.; Jafarizadeh-Malmiri, H. Aloe vera leaf extract mediated green synthesis of selenium nanoparticles and assessment of their In vitro antimicrobial activity against spoilage fungi and pathogenic bacteria strains. Green Process. Synth. 2019, 8, 399-407. [CrossRef]

36. Ramya, S.; Shanmugasundaram, T.; Balagurunathan, R. Biomedical potential of actinobacterially synthesized selenium nanoparticles with special reference to anti-biofilm, anti-oxidant, wound healing, cytotoxic and anti-viral activities. J. Trace Elem. Med. Biol. 2015, 32, 30-39. [CrossRef]

37. Kamaruzaman, N.A.; Yusoff, A.R.M.; Malek, N.A.N.N.; Talib, M. Fabrication, characterization and degradation of electrospun poly(E-caprolactone) infused with selenium nanoparticles. Malays. J. Fundam. Appl. Sci. 2021, 17, 295-305. [CrossRef]

38. Kamaruzaman, N.A.; Yusoff, A.R.M.; Buang, N.A.; Salleh, N.G.N. Effects on diameter and morphology of polycaprolactone nanofibers infused with various concentrations of selenium nanoparticles. Langkawi Malays. 2017, 1901, 020013.

39. Yener, F.; Jirsak, O.; Gemci, R. Using a range of pvb spinning solution to acquire diverse morphology for electrospun nanofibers. Iran. J. Chem. Chem. Eng. (IJCCE) 2012, 31, 49-58.

40. Zhang, Y.; Xiao, C.; An, S.; Yang, J. A morphological study of mullite long fiber prepared using polyvinyl butyral as spinning aids. J. Sol-Gel Sci. Technol. 2011, 57, 142-148. [CrossRef]

41. Imaizumi, S.; Matsumoto, H.; Suzuki, K.; Minagawa, M.; Kimura, M.; Tanioka, A. Phenolic resin-based carbon thin fibers prepared by electrospinning: Additive effects of poly(vinyl butyral) and electrolytes. Polym. J. 2009, 41, 1124-1128. [CrossRef]

42. Lubasova, D.; Martinova, L. Controlled morphology of porous polyvinyl butyral nanofibers. J. Nanomater. 2011, 2021 , e292516. [CrossRef]

43. Chen, L.-J.; Liao, J.-D.; Lin, S.-J.; Chuang, Y.-J.; Fu, Y.-S. Synthesis and characterization of PVB/silica nanofibers by electrospinning process. Polymer 2009, 50, 3516-3521. [CrossRef]

44. Ruediger, T.; Berg, A.; Guellmar, A.; Rode, C.; Schnabelrauch, M.; Urbanek, A.; Wagner, K.; Wyrwa, R.; Kinne, R.W.; Sigusch, B.W. Cytocompatibility of polymer-based periodontal bone substitutes in gingival fibroblast and MC3T3 osteoblast cell cultures. Dent. Mater. 2012, 28, e239-e249. [CrossRef]

45. Posavec, D.; Dorsch, A.; Bogner, U.; Bernhardt, G.; Nagl, S. Polyvinyl butyral nanobeads: Preparation, characterization, biocompatibility and cancer cell uptake. Microchim. Acta 2011, 173, 391-399. [CrossRef]

46. Teo, W.E.; Ramakrishna, S. A review on electrospinning design and nanofibre assemblies. Nanotechnology 2006, 17, R89-R106. [CrossRef] [PubMed]

47. Badgar, K.; Prokisch, J. A simple method for preparing elemental selenium nano- coating inside a silicone surface. Acta Agrar. Debr. 2021, 1, 35-43. [CrossRef]

48. Khandsuren, B.; Prokisch, J. Preparation of red and grey elemental selenium for food fortification. Acta Aliment. 2021, 50, 289-298.

49. Xiong, Y.; Xia, Y. Shape-controlled synthesis of metal nanostructures: The case of palladium. Adv. Mater. 2007, 19, 3385-3391. [CrossRef]

50. Lala, N.L.; Ramaseshan, R.; Bojun, L.; Sundarrajan, S.; Barhate, R.S.; Ying-Jun, L.; Ramakrishna, S. Fabrication of nanofibers with antimicrobial functionality used as filters: Protection against bacterial contaminants. Biotechnol. Bioeng. 2007, 97, 1357-1365. [CrossRef] [PubMed]

51. Lubasova, D.; Netravali, A.N. A novel method for electrospinning nanofibrous 3-D. structures. Fibers 2020, 8, 27. [CrossRef] 